\title{
Extraction and Optimization of Natural Dye from Hambo Hambo (Cassia singueana) Plant Used for Coloration of Tanned Leather Materials
}

\author{
Taame Berhanu and Saminathan Ratnapandian \\ Ethiopian Institute of Textile and Fashion Technology (EiTEX), Bahir Dar University, P.O. Box 1037 Bahir Dar, Ethiopia
}

Correspondence should be addressed to Saminathan Ratnapandian; drsnrtex@gmail.com

Received 15 May 2017; Accepted 21 June 2017; Published 27 July 2017

Academic Editor: Frederic Dumur

Copyright (C) 2017 Taame Berhanu and Saminathan Ratnapandian. This is an open access article distributed under the Creative Commons Attribution License, which permits unrestricted use, distribution, and reproduction in any medium, provided the original work is properly cited.

\begin{abstract}
This investigation was aimed at introducing natural dye extracted from the bark of Cassia Singueana plant for dyeing chrome tanned sheep skin crust leather. The colorant was extracted by aqueous extraction and its strength evaluated using UV-Visible spectroscopy. The extraction with the highest strength (3.9 at $\lambda_{\max }$ of $400 \mathrm{~nm}$ ) was obtained at temperature of $95^{\circ} \mathrm{C}$, concentration of $60 \mathrm{~g} / \mathrm{l}$, and time of 60 minutes. The possibility of using aloe vera juice and mango bark extract as natural mordants for leather coloration was investigated. Dyeing was conducted with and without mordant using different combinations of temperature, time, $\mathrm{pH}$, and concentration of mordants. All three mordanting techniques were evaluated. The color strength $(K / S), \operatorname{CIE} L^{*} a^{*} b^{*}$ values, and fastness properties (light, rubbing, and perspiration) of dyed leather samples were evaluated using appropriate instruments and according to international standards. Majority of samples exhibited that fastness result was in the range of good-excellent. Significantly better color fastness was obtained in case of leather samples premordanted with aloe vera. This study leads to the conclusion that dye extracted from bark of Cassia singueana can be used as colorant for tanned leather with the selected natural mordants.
\end{abstract}

\section{Introduction}

Prior to the invention of artificial dyes mankind used natural colorants derived from plants, animals, soil, insects, and minerals. Such colorants were employed for the coloration of human and animal skins, hair, teeth, bones, all types of vegetable fibers, and woods in a wide range of colors [1] (Panhwar and Abro, 2007; Zereen, Khan, and Ajaib, 2013). Starting from 1856 synthetic dyes have been widely used for leather and textile coloration. But since these synthetic dyes are produced from nonrenewable petroleum [2] they do not only destroy the environment during synthesis but also discharge effluents into water bodies during application that affect aquatic life $[3,4]$. The leather industry consumes large amount of azo dyes [5] which is a class of harmful synthetic dyes [6]. The adverse features of synthetic dyes advocate the need for benign alternatives for leather coloration.

The aspect of producing leather products with minimal impact on the ecological balance, affecting both human and environmental health, is an important focal point to be pursued. Starting from late 20th century researchers concentrated on using natural colorants in leather dyeing. Investigations have been reported on dye extraction from plant sources such as beetroot [7], henna leaves [8], eucalyptus bark, tea leaves, turmeric rhizomes, walnut bark [9], and Rubia tinctorum roots [10]. Keeping in line with the above efforts, this study was carried out to color chrome tanned sheep skin crust leather using dye extracted from Cassia singueana (Amharic hambo hambo). The use of this plant although known to local dyers as a traditional dye for leather has not been optimized in terms of extraction and dyeing parameters. Available literature however cites the use of the plant in northern Nigeria as an antimicrobial agent and panacea for acute malaria $[11,12]$. The purpose of this research is to highlight the use of hambo hambo as a source of dye and optimize the extraction and subsequent coloration processes. The efforts are expected not only to aid the local dyers but also 
to introduce a sustainable colorant for the leather processing industry.

\section{Materials and Methods}

2.1. Materials. The bark of Cassia singueana and fresh aloe vera leaves were collected from Tigray region and mango bark was collected from Bahir Dar, Ethiopia. Fresh leaves of aloe vera were collected manually using knife during winter season (January) and washed thoroughly to remove impurities. Immediately after washing, the outer green surface was peeled off and the inner white mass was collected and crushed to semisolid form using electronic agitator of juice crusher tool with $(W \times H \times D: 12.7 \mathrm{~cm} \times 33 \mathrm{~cm} \times 22.86 \mathrm{~cm})$.

Two full-size chrome tanned wet blue sheep skin crust leather were obtained from Ethiopian leather industry development institute (LIDI), Addis Ababa, Ethiopia.

Sheep skin was pretanned (liming, soaking, hair removal, deliming, etc.) to remove the hair, blood, preservatives, and impurities from the skin. The pretanned skin was tanned with trivalent chrome $\left(\mathrm{Cr}_{2} \mathrm{O}_{3}\right)$ to improve flexibility, strength, and performance. Finally the tanned skin was posttanned (summing, shaving, splitting, neutralizing, and fat liquoring) to get the crust sheep skin leather which is ready for dyeing.

Copper sulphate, sodium carbonate, and formic acid were of LR (laboratory reagent) grade indicating a purity of $99 \%$ and sourced from LIDI.

\subsection{Methods}

2.2.1. Dye Extraction. Aqueous extraction method was employed for obtaining coloring components from the bark of hambo hambo plant. Bark was collected and washed thoroughly with water to remove soil and dust particles as suggested by earlier researchers $[13,14]$. The washed bark was shade-dried, ground, and sieved resulting in a fine powder. The powder was soaked in distilled water at concentrations of $(20,40$, and $60 \mathrm{~g} / \mathrm{l})$ for 24 hours. Subsequently the mixture was subjected to different temperatures $\left(45,75\right.$, and $\left.90^{\circ} \mathrm{C}\right)$ and time $(30,45$, and 60 minute) combinations individually. The resultant solution was filtered and its absorption determined by UV-Visible spectroscopy. The temperature, concentration, and time combination yielding the maximum absorption were taken as optimum condition for extraction of dye.

2.2.2. Mordant Extraction. Mango bark powder was prepared following procedure similar to that mentioned for hambo hambo. Extraction was carried out using a concentration of $7.5 \mathrm{~g} / 100 \mathrm{ml}$ and temperature of $90^{\circ} \mathrm{C}$ for 1 hour as outlined by [15]. The filtrate was used as mordant for dyeing of leather.

Aloe vera mordant was prepared in accordance with procedure mentioned by [16]. $150 \mathrm{~g}$ of white inner part of aloe vera leaf was crushed, heated at $100^{\circ} \mathrm{C}$ for 1 hour, and then filtered to obtain the mordant solution.

2.2.3. Mordanting. Natural dyes typically have low affinity to textile and leather as compared to synthetic dyes. Consequently they often require mordants to improve substantivity [1]. All three mordanting techniques, that is, premordanting,
TABLE 1: Different parameters combinations used to dye leather.

\begin{tabular}{lccc}
\hline Sample number & $\mathrm{pH}$ & Temperature $\left({ }^{\circ} \mathrm{C}\right)$ & Time \\
\hline 1 & 5.5 & 25 & 20 \\
2 & 5 & 40 & 30 \\
3 & 4.5 & 55 & 45 \\
4 & 4 & 70 & 60 \\
\hline
\end{tabular}

postmordant, and simultaneous mordanting were evaluated for both mordants individually. Four concentrations of 10, 20, 30 , and $40 \mathrm{~g} / \mathrm{l}$ were evaluated for each mordant. Mordanting with copper sulphate (by all three methods) at 3\% on weight of material (OWM) was employed as reference. In all the trials treatment temperature of $60^{\circ} \mathrm{C}$ and time of 60 minutes were maintained constant.

2.2.4. Dyeing. A sample of 25 grams of tanned leather was dyed with extracted dye concentration of $60 \mathrm{~g} / \mathrm{l}$ and natural mordant concentration of 10, 20,30, and $40 \mathrm{~g} / \mathrm{l}$, and $3 \% \mathrm{OWM}$ of copper sulphate was used for all trials. Combinations of $\mathrm{pH}$, temperature, and time identified using Minitab software, listed in Table 1, were employed in order to optimize dyeing parameters. The combination yielding highest $K / S$ value of dyed leather was selected as optimum condition.

\subsection{Evaluation of Dyed Leather}

2.3.1. Color Strength (K/S Value), Reflectance (\%), and CIE $L^{*} a^{*} b^{*}$ Determination. The color of dyed samples was measured using spectrophotometer (COLOR EYE-3100) in terms of color strength $(K / S)$, reflectance $(\%)$, and CIE $L^{*} a^{*} b^{*}$ values.

Color fastness to rubbing, perspiration, and light were determined as per standard test method of ISO 11640, ISO 11641, and EN ISO 105-B02, respectively.

\section{Results and Discussion}

3.1. Dye Extraction Parameter Optimization. Natural dye was extracted from the bark of Cassia singueana using various combinations of temperature, time, and bark powder concentration. The absorption of resultant solution was determined using UV-Visible spectroscopy (Lambda 25) and shown in Table 2. Maximum absorption (3.9) was obtained from trial seven and therefore concentration of $60 \mathrm{~g} / \mathrm{l}$, temperature of $95^{\circ} \mathrm{C}$, and time of $60 \mathrm{~min}$ were selected as optimum.

3.1.1. Color Strength (K/S) Value, Reflectance (\%), and CIE $L^{*} a^{*} b^{*}$ Value. Color developed and color strength on dyed leather samples were evaluated in terms of their CIE $L^{*} a^{*} b^{*}$ coordinates and $K / S$ values at $10^{\circ}$ observer. The $L^{*}$ (lightness/darkness), $a^{*}$ (redness/greenness), and $b^{*}$ (yellowness/blueness) value of dyed leather samples obtained from all dyeing and mordanting methods were laid in dark gray to light gray, red, and yellow direction, respectively. The darkness value of copper mordanted dyed leather samples was higher than that of directly dyed leather samples and 
TABLE 2: Absorption values of dye solution from bark of Cassia singueana.

\begin{tabular}{lcccc}
\hline Number of trials & Temperature $\left({ }^{\circ} \mathrm{C}\right)$ & Concentration of the bark powder $(\mathrm{g} / \mathrm{l})$ & Time $(\mathrm{min})$ & Absorption \\
\hline Trial 1 & 45 & 20 & 60 & 30 \\
Trial 2 & 45 & 20 & 30 & 1.8 \\
Trial 3 & 45 & 60 & 60 & 3.7 \\
Trial 4 & 45 & 60 & 45 & 3.6 \\
Trial 5 & 75 & 40 & 60 & 3.49 \\
Trial 6 & 95 & 60 & 60 & 3.05 \\
Trial 7 & 95 & 60 & 3.9 \\
Trial 8 & 95 & 20 & 30 & 2.25 \\
Trial 9 & 95 & 20 & & 30 \\
\hline
\end{tabular}

TABLE 3: Color strength $(K / S)$ value, reflectance (\%), and CIE $L^{*} a^{*} b^{*}$ values of selected dyed leather samples.

\begin{tabular}{|c|c|c|c|c|c|}
\hline \multirow{2}{*}{ Method } & \multirow{2}{*}{ Reflectance (\%) at $400 \mathrm{~nm}$} & \multirow{2}{*}{$K / S$ at $400 \mathrm{~nm}$} & \multicolumn{3}{|c|}{ CIE $L^{*} a^{*} b^{*}$ system } \\
\hline & & & $L^{*}$ & $a^{*}$ & $b^{*}$ \\
\hline SM with copper sulphate & 4.03 & 11.42 & 33.77 & 15.57 & 16.96 \\
\hline Dyed without mordant & 4.07 & 11.30 & 39.09 & 28.40 & 23.75 \\
\hline PRM with aloe vera & 6.78 & 7.28 & 50.87 & 26.12 & 29.75 \\
\hline PRM with mango bark & 6.46 & 6.77 & 50.50 & 18.01 & 26.63 \\
\hline
\end{tabular}

PRM = premordanted; $\mathrm{SM}=$ simultaneously mordanted.

mordanted with aloe vera and mango bark, while the darkness of direct dyed leather was higher than those mordanted with aloe vera and mango bark as shown in Table 3.

All dyed leather samples are in the red direction which was reflected in $a^{*}$ and yellow direction in $b^{*}$ as shown in the CIE $L^{*} a^{*} b^{*}$ color space. The value of $a^{*}$ (redness) obtained in directly dyed leather samples was higher than the samples mordanted with the three mordants in all mordanting techniques.

The value of $b^{*}$ (yellowness) obtained from dyed samples which are premordanted with aloe vera was higher than all other dyed samples.

Shade of color was changed in some specimens mordanted with mango bark, aloe vera, and copper sulphate mordants as shown in Figure 4. Similar to results of [17] the mordants used in the combination gave varying shades resulting in inconsistency of color value results [17].

3.1.2. Reflectance (\%) and K/S Values of Dyed Leather Samples. In directly dyed leather samples, the maximum dye absorption $(K / S)$ value and minimum reflectance $(\%)$ were obtained from sample dyed at temperature of $70^{\circ} \mathrm{C}$, time of $60 \mathrm{~min}$, and $\mathrm{pH}$ of 4 as shown in Figures 1 and 2. This sample was taken as optimum condition for dyeing of chrome tanned leather with dye extracted from bark of Cassia singueana plant. When mordanted with aloe vera and mango bark, the maximum $K / S$ value was obtained from premordanted samples. In case of samples treated with copper sulphate, simultaneously mordanted sample yielded maximum color strength at temperature of $60^{\circ} \mathrm{C}$, time of $60 \mathrm{~min}$, and $\mathrm{pH}$ of 3.5. In general, it was observed that the best $K / S$ value was obtained from samples dyed at temperature of $70^{\circ} \mathrm{C}$, time of $60 \mathrm{~min}$, and $\mathrm{pH}$ of 4 in all samples mordanted with natural mordants.

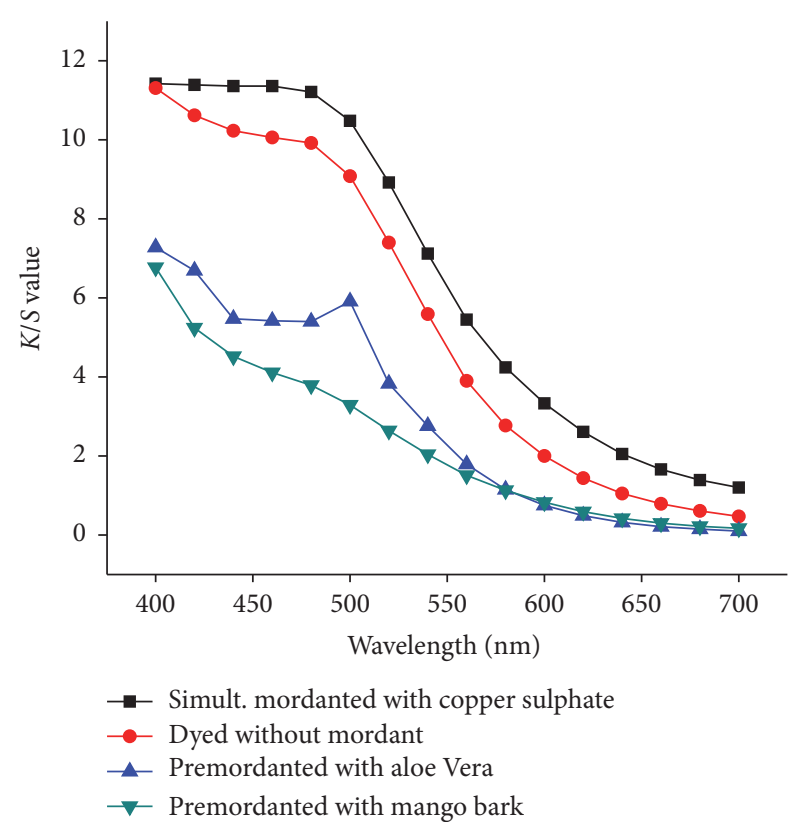

FIGURE 1: Effect of mordant and $\mathrm{pH}$ on $K / S$ of dyed leather samples.

3.1.3. Effect of Mordanting Techniques. Natural mordants of aloe vera and mango bark gave best shades with premordanting. In case of copper sulphate simultaneous mordanting yielded best results as shown in Figure 3 .

3.2. Fastness Results. The fastness properties of dyed leather samples were tested by standard ISO method. The performance of light fastness, fastness to perspiration, and rubbing of the specimens are presented in Table 4. It can be observed 
TABLE 4: Color fastness properties of dyed leather samples.

\begin{tabular}{|c|c|c|c|c|c|c|}
\hline \multirow{2}{*}{ Method of mordanting } & \multirow{2}{*}{ Mordant concentration } & \multicolumn{2}{|c|}{ Rubbing fastness } & \multirow{2}{*}{$\begin{array}{l}\text { Light fastness } \\
24 \mathrm{hr}\end{array}$} & \multicolumn{2}{|c|}{ Fastness to perspiration } \\
\hline & & Dry & Wet & & Acidic & Basic \\
\hline Simultaneous mordanted with copper sulphate & $3 \%$ (owm) & 5 & 5 & 8 & $4 / 5$ & 5 \\
\hline Dyed without mordant & Nil & 5 & $4 / 5$ & 6 & 4 & 5 \\
\hline Premordanted with aloe vera & $40 \mathrm{~g} / \mathrm{l}$ & 5 & $4 / 5$ & 6 & $4 / 5$ & 5 \\
\hline Premordanted with mango bark & $40 \mathrm{~g} / \mathrm{l}$ & $4 / 5$ & $3 / 4$ & $5-6$ & 4 & 3 \\
\hline
\end{tabular}

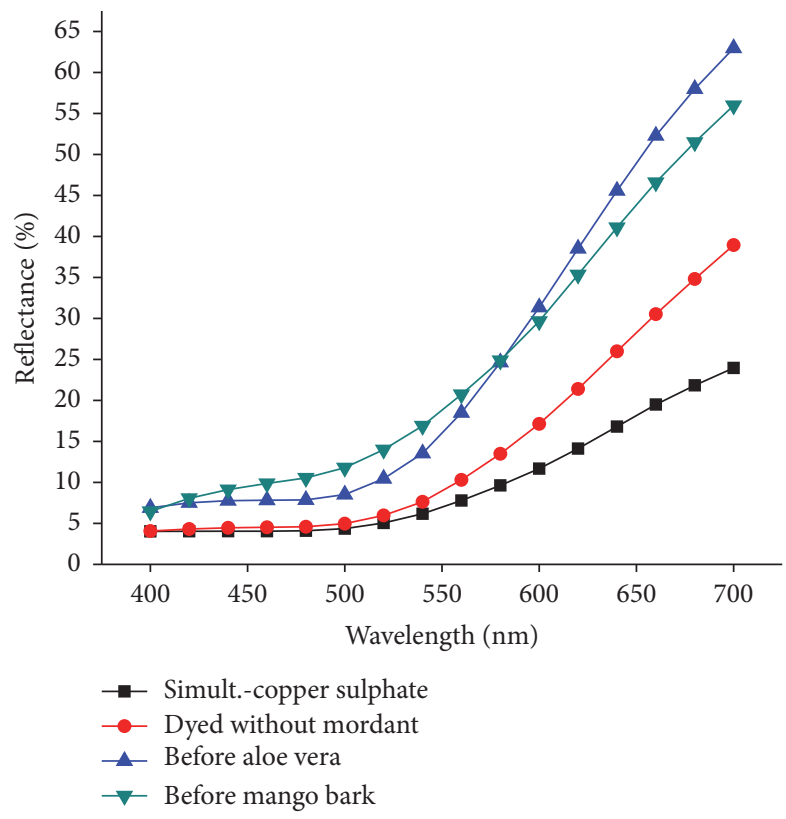

FIGURE 2: Reflectance spectra of selected dyed leather samples.

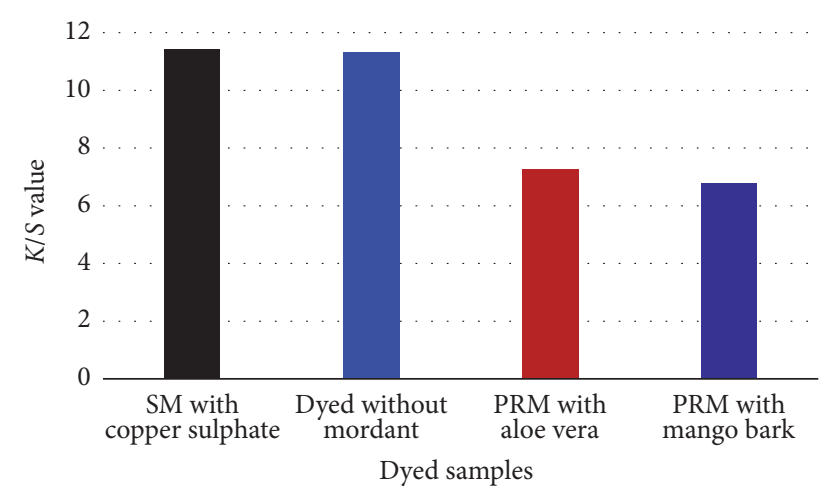

Figure 3: Maximum $(K / S)$ value of selected dyed leather samples at wavelength of $400 \mathrm{~nm}$.

that directly dyed sample and those premordanted with natural mordants exhibit good to excellent rubbing and perspiration fastness and good to very good light fastness. In general, natural dye extracted from bark of Cassia singueana could be used for commercial purposes.

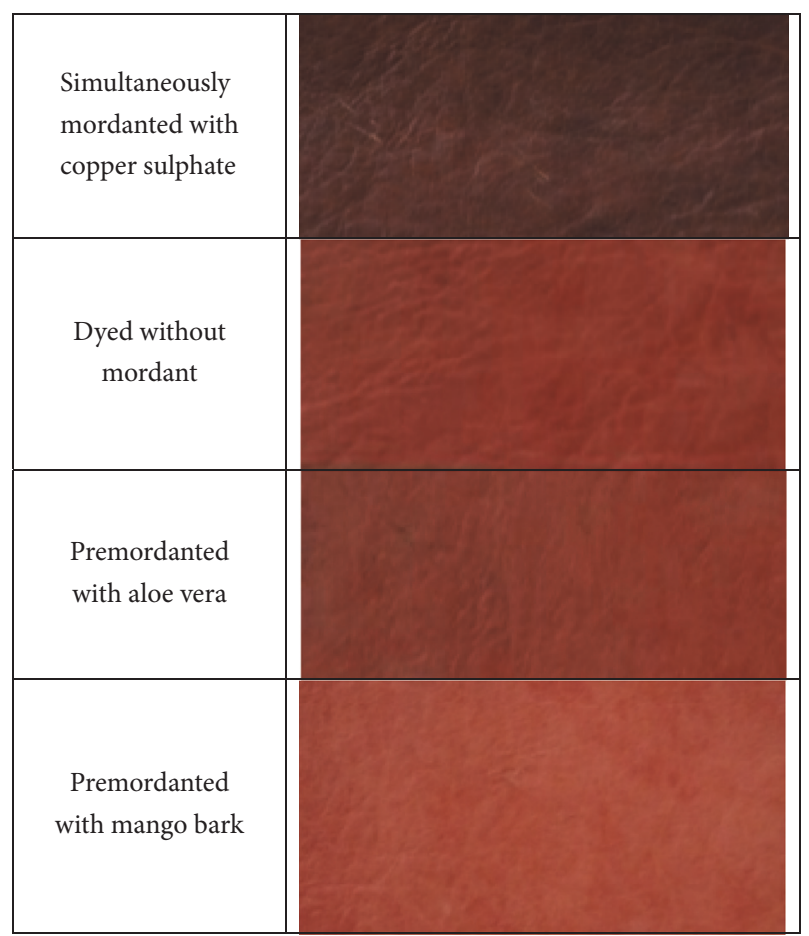

FIGURE 4: Color produced on leather samples with best color strength $(K / S)$ value.

\section{Conclusions}

The present study revealed that dye extracted from bark of Cassia singueana can be used as dye for coloring of tanned leather. Abundant availability in Ethiopia makes the raw material cheap. The use of this plant for coloration of leather would reduce import of synthetic dyes and provide additional cash crop for farmers. The possibility of employing natural mordants (extracts of mango bark and aloe vera juice) provides additional attraction. The acceptable performance ratings make the process commercially viable.

\section{Disclosure}

Taame Berhanu is presently working as Lecturer in Textile Chemistry at Dire Dawa Institute of Technology (DDIT), Dire Dawa University, Dire Dawa, Ethiopia. 


\section{Conflicts of Interest}

The authors declare that they have no conflicts of interest.

\section{Acknowledgments}

The authors are grateful to Assistant Professor Addisu Ferede, Scientific Director, and Assistant Professor Adane Haile, Textile Chemistry RIC Director, EiTEX, Bahir Dar University, Ethiopia, for their encouragement and support in conducting this research. Besides authors would like to thank Dire Dawa University, Ethiopia, for their financial support to do this Master thesis.

\section{References}

[1] D. Cardon, Natural Dyes: Sources, Tradition, Technology and Science, Archetype, London, UK, 2007.

[2] M. Devi, V. Ariharan, and P. N. Prasad, "Annato: eco-friendly and potential source for natural dye," International Research Journal of Pharmacy, vol. 4, no. 6, pp. 106-108, 2013.

[3] V. K. Gupta, R. Kumar, A. Nayak, T. A. Saleh, and M. A. Barakat, "Adsorptive removal of dyes from aqueous solution onto carbon nanotubes: a review," Advances in Colloid and Interface Science, vol. 193-194, pp. 24-34, 2013.

[4] C. Zaharia, D. Şuteu, and A. Mureşan, "Options and solutions for textile effluent decolorization using some specific physico-chemical treatment steps," Environmental Engineering and Management Journal, vol. 11, no. 2, pp. 493-509, 2012.

[5] M. Sudha, A. Saranya, G. Selvakumar, and N. Sivakumar, "Microbial degradation of azo dyes: a review," International Journal of Current Microbiology and Applied Sciences, vol. 3, no. 2, pp. 670-690, 2014.

[6] R. G. Saratale, G. D. Saratale, J. S. Chang, and S. P. Govindwar, "Bacterial decolorization and degradation of azo dyes: a review," Journal of the Taiwan Institute of Chemical Engineers, vol. 42, no. 1, pp. 138-157, 2011.

[7] V. Sivakumar, J. L. Anna, J. Vijayeeswarri, and G. Swaminathan, "Ultrasound assisted enhancement in natural dye extraction from beetroot for industrial applications and natural dyeing of leather," Ultrasonics Sonochemistry, vol. 16, no. 6, pp. 782-789, 2009.

[8] A. E. Musa, B. Madhan, W. Madhulatha, J. R. Rao, G. A. Gasmelseed, and S. Sadulla, "Coloring of leather using henna-natural alternative material for dyeing," Journal of the American Leather Chemists Association, vol. 104, no. 5, pp. 183190, 2009.

[9] A. Inayat, S. R. Khan, A. Waheed, and F. Deeba, "Applications of eco friendly natural dyes on leather using different modrants," Proceedings of the Pakistan Academy of Sciences, vol. 47, no. 3, pp. 131-135, 2010.

[10] E. Önem, G. Gülümser, and B. Ocak, "Evaluation of natural dyeing of leather with Rubia tinctorum extract," Ekoloji Dergisi, vol. 20, no. 80, pp. 81-87, 2011.

[11] B. Adzu, J. Abbah, H. Vongtau, and K. Gamaniel, "Studies on the use of Cassia singueana in malaria ethnopharmacy," Journal of Ethnopharmacology, vol. 88, no. 2-3, pp. 261-267, 2003.

[12] M. Endo and H. Naoki, "Antimicrobial and antispasmodic tetrahydroanthracenes from Cassia singueana," Tetrahedron, vol. 36, no. 17, pp. 2449-2452, 1980.
[13] S. Pervaiz, M. Aziz, Z. Khan, and M. Najeebullah, "Floral dyes: an opportunity for punjab leather industry to promote sustainable fashion development," International Journal of Research in Advent Technology, vol. 4, no. 8, pp. 34-39, 2016.

[14] Z. M. Win and M. M. Swe, "Purification of the natural dyestuff extracted from Mango bark for the application on protein fibers," World Academy of Science, Engineering and Technology, vol. 22, pp. 536-540, 2008.

[15] L. M. Wangatia, K. Tadesse, and S. Moyo, "Mango bark mordant for dyeing cotton with natural dye: fully eco-friendly natural dyeing," International Journal of Textile Science, vol. 4, no. 2, pp. 36-41, 2015.

[16] P. Nilani, B. Duraisamy, P. Dhamodaran, N. Kasthuribai, S. Alok, and B. Suresh, "A study on the effect of marigold flower Dye with natural mordant on selected Fibers," Journal of Pharmacy Research, vol. 1, no. 2, pp. 175-181, 2008.

[17] M. M. Kamel, F. Abdelghaffar, and M. M. El-Zawahry, "Ecofriendly dyeing of wool with a mixture of natural dyes," Journal of Natural Fibers, vol. 8, no. 4, pp. 289-307, 2011. 

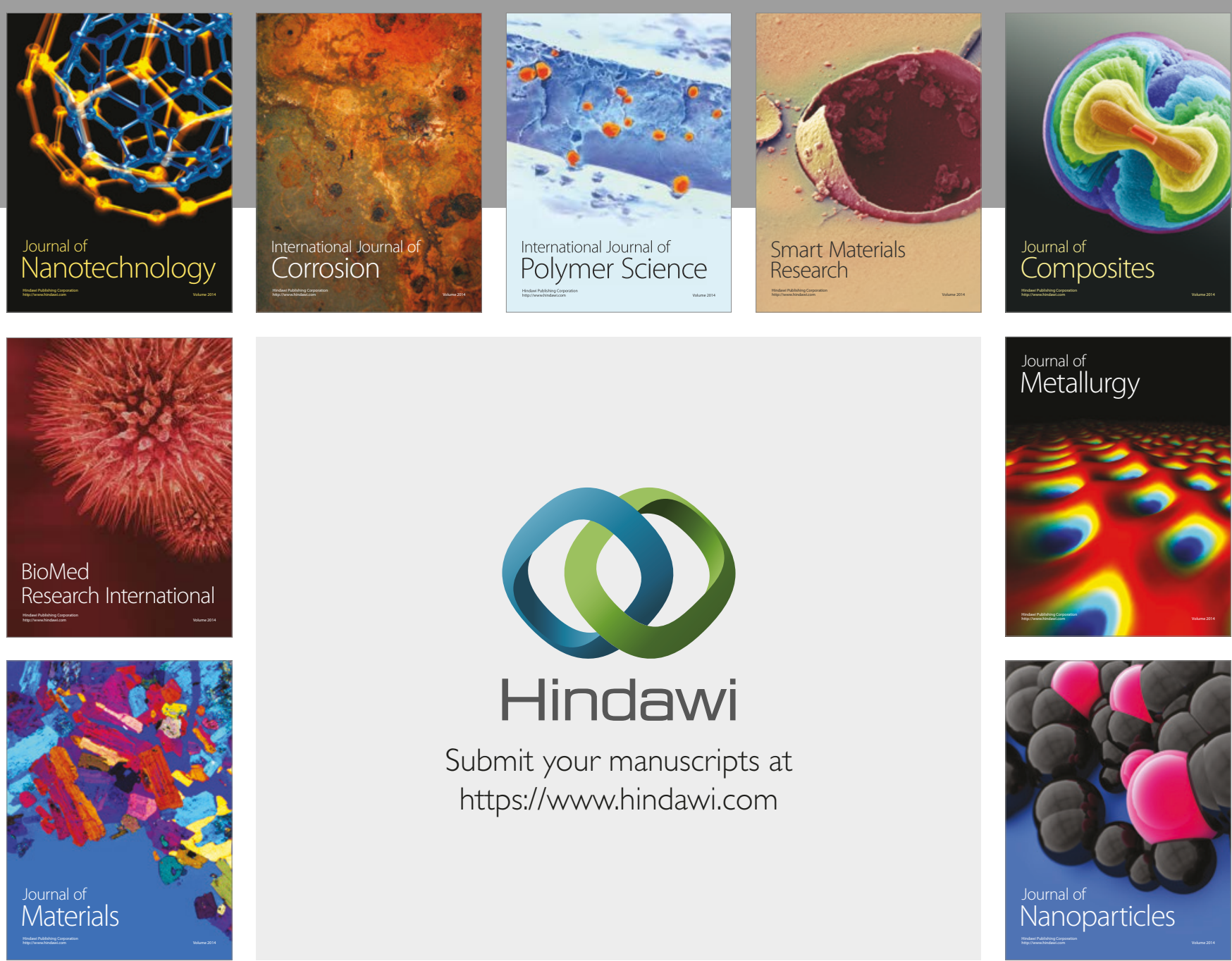

\section{Hindawi}

Submit your manuscripts at

https://www.hindawi.com
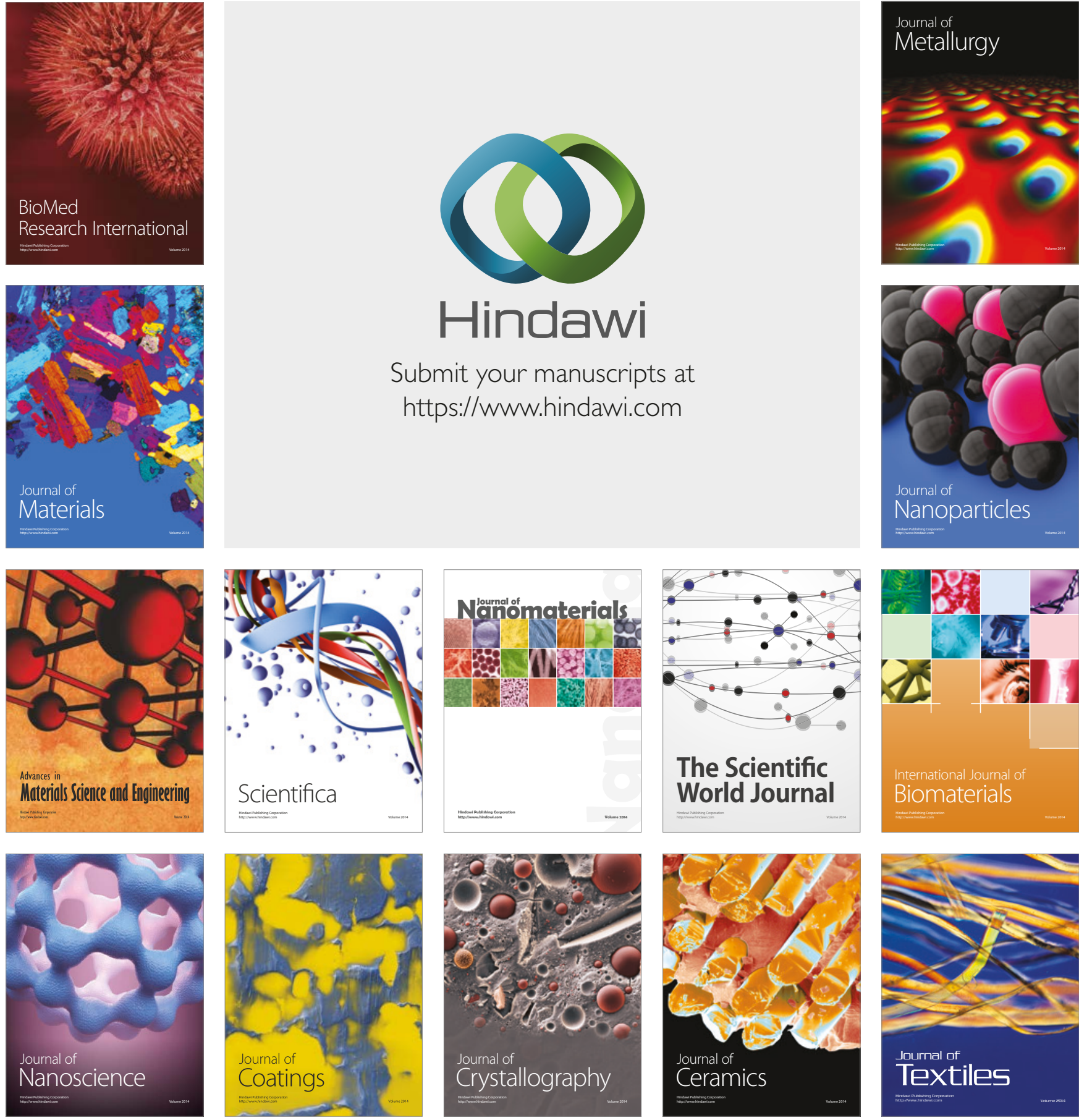

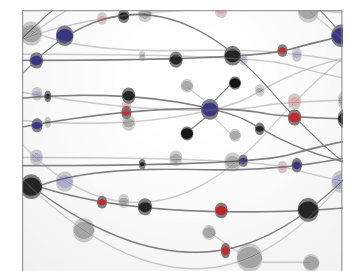

The Scientific World Journal
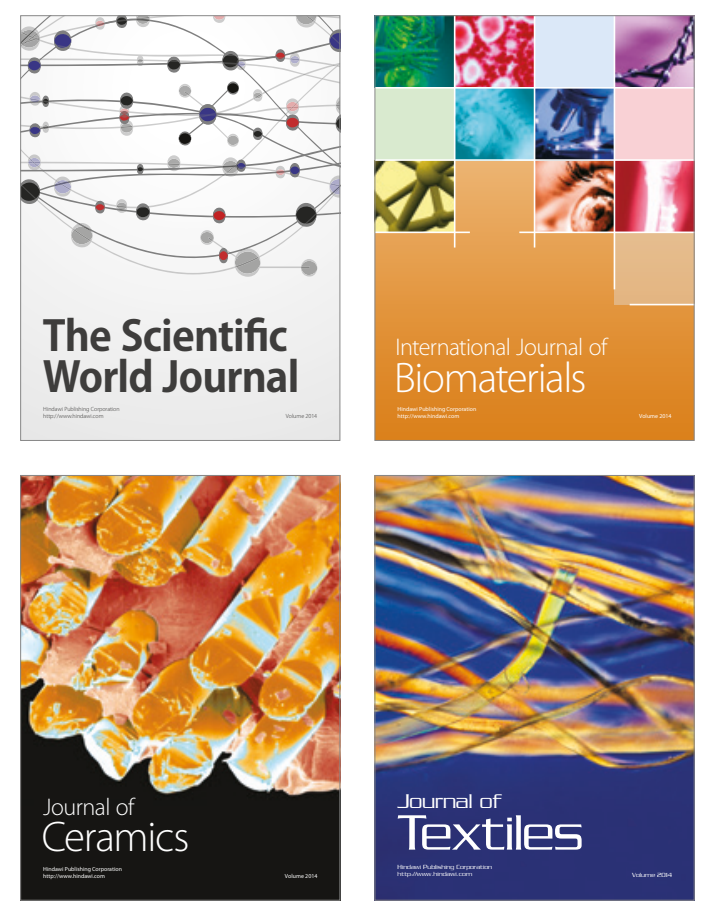